\title{
Hubungan antara Kebiasaan Merokok dan Hipertrofi Ventrikel Kiri pada Laki-laki Dewasa Muda dengan Obesitas Sentral
}

\author{
Ribka Wowor \\ Fakultas Kesehatan Masyarakat Universitas Sam Ratulangi Manado \\ Email: ribkaladywowor@gmail.com
}

\begin{abstract}
Left ventricular hypertrophy $(\mathrm{LVH})$ is an independent risk factor for mortality. This state should be prevented by controlling the underlying factor, such as smoking. This study was aimed to determine the association between smoking and left ventricular hypertrophy in young adult men with central obesity. This was a case control study, conducted at Cardiology Department of Prof. Dr. R. D. Kandou Hospital in Manado from January to March 2015. Subjects were young adult male students (18-30 years old) at Prof. Dr. R. D. Kandou Hospital with central obesity divided into two groups: case group and control group. The case group consisted of 31 subjects with LVH meanwhile the control group consisted of 21 subjects without $\mathrm{LVH}$. The statistical analysis showed that smoking was a risk factor for LVH in young adult men with central obesity, but not statistically significant (OR=3.846; 95\% CI: 0.494-14.901; $P=0.432$ ). Conclusion: Smoking is a risk factor of left ventricular hypertrophy in young adult men ( $<30$ years old) with central obesity, but not statistically significant.
\end{abstract}

Keywords: smoking, left ventricular hypertrophy, young adult men, central obesity

\begin{abstract}
Abstrak: Hipertrofi ventrikel kiri (HVK) merupakan salah satu prediktor kematian independen. Pembesaran jantung kiri sebenarnya merupakan keadaan yang dapat dicegah dengan pengendalian faktor risiko, salah satunya ialah merokok. Penelitian ini bertujuan untuk mengetahui hubungan antara kebiasaan merokok dan hipertrofi ventrikel kiri pada laki-laki dewasa muda dengan obesitas sentral. Jenis penelitian ialah penelitian kuantitatif metode analitik dengan menggunakan rancangan case-control. Penelitian dilaksanakan di Bagian Kardiologi RSUP Prof. Dr. R. D. Kandou Manado selama 3 (tiga) bulan, yaitu dari bulan Januari 2015 s/d Maret 2015. Subyek penelitian ialah laki-laki dewasa muda (usia 18-30 tahun) dengan obesitas sentral dan sementara menjalani KKM di RSUP Prof. Dr. R. D. Kandou Manado. Subyek yang mengalami HVK sebagai kelompok kasus dan yang tidak mengalami HVK sebagai kelompok kontrol. Hasil penelitian mendapatkan bahwa kebiasaan merokok merupakan faktor risiko terjadinya HVK pada laki-laki dewasa muda dengan obesitas sentral walaupun secara statistik tidak bermakna (OR=3,846; 95\% CI: 0,494-14,901; $P=0,432)$. Simpulan: Kebiasaan merokok merupakan faktor risiko terjadinya pembesaran jantung kiri pada laki-laki dewasa muda ( $<30$ tahun), walaupun secara statistik tidak bermakna.
\end{abstract}

Kata kunci: merokok, hipertrofi ventrikel kiri, dewasa muda, obesitas sentral

Hipertrofi ventrikel kiri (HVK) merupakan salah satu prediktor kematian independen. Sejak lebih dari 40 tahun lalu, Framingham Heart Study telah membuktikan bahwa HVK yang didiagnosis dengan elektrokardiografi berhubungan erat dengan risiko sudden cardiac death (SCD), penyakit jantung koroner (PJK), dan penyakit kardiovaskular lainnya. ${ }^{1}$

Prevalensi HVK pada populasi di Amerika Serikat sekitar 15-20\%; lebih sering terdapat pada laki-laki, lanjut usia, 
hipertensi, dan obesitas. ${ }^{1}$ Di Indonesia belum terdapat data mengenai jumlah HVK pada populasi umum, namun pada pasien hipertensi sekitar 50\% di antaranya telah mengalami HVK. ${ }^{2}$

Hipertrofi ventrikel kiri sebagai faktor risiko indipenden, juga berperan penting dalam terjadinya gagal jantung (congestive heart failure, $\mathrm{CHF}$ ). Prevalensi gagal jantung berdasarkan yang terdiagnosis dokter atau gejala sebesar $0,3 \%$. Prevalensi gagal jantung berdasarkan terdiagnosis dokter tertinggi di DI Yogyakarta $(0,25 \%)$, disusul Jawa Timur $(0,19 \%)$, dan Jawa Tengah $(0,18 \%)$. Pasien CHF umumnya nanti terdiagnosis pada usia 50-an dan biasanya telah disertai dengan manifestasi klinis yang agak berat. ${ }^{3}$

Hipertrofi ventrikel kiri sebenarnya merupakan keadaan yang dapat dicegah bila faktor risiko dikendalikan. Beberapa faktor risiko yang mendorong timbulnya HVK antara lain merokok. ${ }^{4}$ Perilaku merokok penduduk Indonesia yang berusia 15 tahun ke atas cenderung meningkat dari $34,2 \%$ tahun 2007 menjadi 36,3\% tahun 2013. Pada tahun 2013, 64,9\% laki-laki dan $2,1 \%$ perempuan masih menghisap rokok. Di samping itu, ditemukan pula $1,4 \%$ perokok usia 10-14 tahun, 9,9\% perokok pada kelompok tidak bekerja, dan 32,3\% pada kelompok kuintil indeks kepemilikan terendah. Rerata jumlah batang rokok yang dihisap ialah sekitar 12,3 batang, bervariasi dari yang terendah 10 batang di DI Yogyakarta dan tertinggi di Bangka Belitung (18,3 batang). ${ }^{3}$

Pada fase permulaan, HVK masih reversibel apabila belum disertai gejala gagal jantung. Penurunan berat badan dan lingkar perut akan menurunkan kadar inflamasi dalam tubuh sehingga terjadi regresi massa jantung kembali normal. ${ }^{5}$ Penurunan kadar inflamasi juga berlaku pada individu yang berhenti merokok. ${ }^{4}$ Hal ini menunjukkan bahwa penting untuk melakukan deteksi dini HVK pada individu yang memiliki faktor risiko, antara lain yang disertai obesitas sentral dan merokok, walaupun masih berusia muda.

\section{METODE PENELITIAN}

Jenis penelitian ini ialah kuantitatif metode analitik dengan menggunakan rancangan case-control. Penelitian dilaksanakan di Bagian Kardiologi RSUP Prof. Dr. R. D. Kandou Manado selama 3 (tiga) bulan, yaitu dari Januari 2015 s/d Maret 2015.

Populasi ialah mahasiswa laki-laki peserta Kepaniteraan Klinik Madya (KKM) Fakultas Kedokteran Universitas Sam Ratulangi di RSUP Prof. Dr. R. D. Kandou Manado yang berusia antara 18-30 tahun dengan obesitas sentral. Subyek penelitian ialah 31 mahasiswa dengan HVK (kelompok kasus) dan 21 mahasiswa tanpa HVK (kelompok kontrol)

Hipertrofi ventrikel kiri adalah penambahan indeks massa ventrikel kiri lebih dari $115 \mathrm{~g} / \mathrm{m}^{2}{ }^{6}$ Indeks massa ventrikel kiri dievaluasi menggunakan ekokardiogram 2 dimensi dan M-Mode dengan posisi subyek berbaring terlentang agak menghadap ke kiri. ${ }^{7}$ Kebiasaan merokok adalah kebiasaan atau perilaku seseorang menghisap rokok dan atau pernah merokok sebelum terdiagnosis pembesaran jantung kiri. Cara ukur melalui wawancara dengan subyek penelitian, yaitu merokok selama minimal 2 tahun setiap hari minimal 1 batang; dan tidak merokok ialah tidak pernah merokok minimal selama 3 tahun terakhir. Data yang diperoleh ditabulasi dan diuji kemaknaannya dengan uji chi-Square.

\section{HASIL PENELITIAN}

Tabel 1 memperlihatkan bahwa subyek paling banyak berada pada kelompok usia 21-25 tahun dan paling sedikit pada kelompok usia 16-20 tahun dengan rerata usia 23,2 tahun pada kelompok kasus dan 22,7 tahun pada kelompok kontrol. Terdapat perbedaan bermakna antara rerata lingkar perut kelompok kasus $(104,12 \mathrm{~cm})$ bila dibandingkan dengan kelompok kontrol $(97,19 \mathrm{~cm})$. Demikian pula dengan tekanan darah sistolik $(129,19$ vs 122,38 $\mathrm{mm} \mathrm{Hg})$ dan tekanan darah diastolik $(84,52$ vs 79,52 $\mathrm{mm} \mathrm{Hg}$ ). 
Gambar 1 menampilkan hasil pengolahan data secara univariat untuk golongan usia subyek berdasarkan kelompok kasus dan kontrol. Golongan usia kelompok kasus dan kelompok kontrol paling banyak ialah golongan usia 21-25 tahun yaitu 16 subyek (50\%) untuk kelompok kasus dan 11 subyek (21,2\%) untuk kelompok kontrol. Golongan usia yang paling sedikit ialah usia 26-30 tahun dengan jumlah 7 subyek $(13,5 \%)$ untuk kelompok kontrol; tidak ada subyek untuk kelompok kasus.

Gambar 2 menunjukkan bahwa subyek yang memiliki kebiasaan merokok paling banyak terdapat pada kelompok kasus yaitu sebanyak 5 orang $(9,6 \%)$, sedangkan pada kelompok kontrol hanya terdapat 1 orang $(1,9 \%)$ dengan kebiasaan merokok. Subyek yang tidak merokok paling banyak didapatkan pada kelompok kasus sebanyak 26 orang $(50 \%)$ dibandingkan 20 otang $(38,5 \%)$ pada kelompok kasus.

Tabel 1. Distribusi subyek berdasarkan karakteristik

\begin{tabular}{lcccccc}
\hline & \multicolumn{3}{c}{ Kasus } & & \multicolumn{3}{c}{ Kontrol } \\
& Min & Maks & Rerata & Min & Maks & Rerata \\
\hline Usia & 20 & 29 & 23,2 & 18 & 25 & 22,7 \\
Lingkar perut & 91 & 128 & 104,12 & 91 & 111 & 97,19 \\
TDS & 120 & 160 & 129,19 & 110 & 140 & 122,38 \\
TDD & 75 & 100 & 84,52 & 70 & 90 & 79,52 \\
\hline
\end{tabular}

Ket: TDS, tekanan darah sistolik; TDD, tekanan darah diastolik
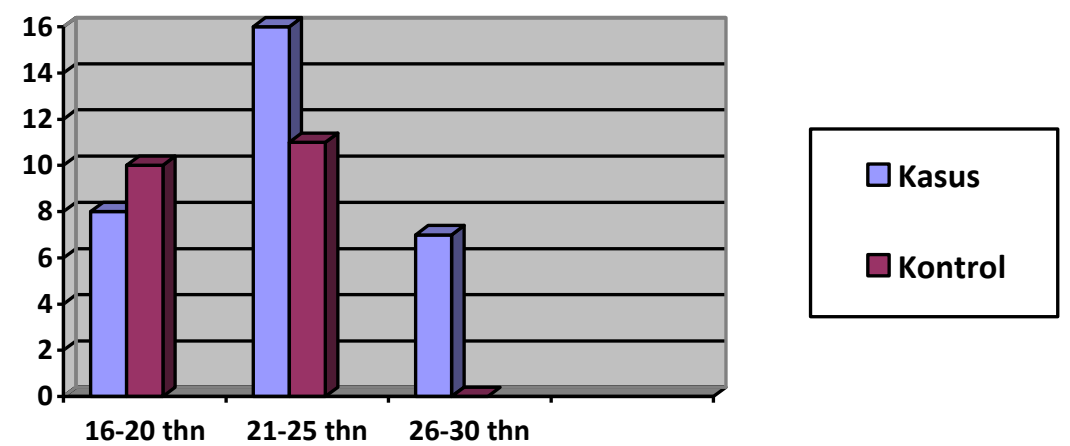

Gambar 1. Distribusi subyek menurut golongan uisa pada kelompok kasus dan kontrol

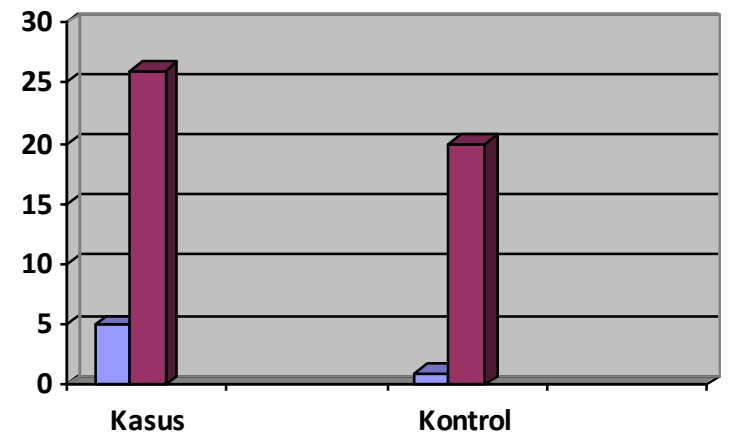

$\square$ Merokok (+)

$\square$ Merokok (-)

Gambar 2. Distribusi subyek menurut ada tidaknya kebiasaan merokok pada kelompok kasus dan kontrol 
Analisis bivariat dilakukan dengan menggunakan uji chi-square dan perhitungan Odd Ratio (OR) pada interval kepercayaan 95\%. Hasil pengolahan data untuk merokok menunjukkan bahwa terdapat 6 subyek $(11,5 \%)$ yang memiliki kebiasaan merokok; 5 orang di antaranya
$(9,6 \%)$ terdapat pada kelompok kasus yang mengalami HVK. Tabel 2 menyajikan hasil uji chi-square yang membuktikan bahwa tidak terdapat hubungan bermakna antara kebiasaan merokok dengan kejadian HVK yang ditunjukkan dengan nilai $P=0,432$; $\mathrm{OR}=3,846$ (95\% CI: 0,494-14,901).

Tabel 2. Pengaruh merokok terhadap kejadian HVK pada subyek penelitian

\begin{tabular}{|c|c|c|c|c|c|c|c|c|}
\hline \multicolumn{6}{|c|}{ Kejadian HVK } & \multicolumn{3}{|c|}{$\begin{array}{l}\text { CI 95\%: } \\
0,494-14,901\end{array}$} \\
\hline Merokok & Kasus & $\%$ & Kontrol & $\%$ & $\mathbf{N}$ & $\%$ & $P$ & OR \\
\hline Ya & 5 & 9,6 & 1 & 1,9 & 6 & 11,5 & 0,432 & 3,846 \\
\hline Tidak & 26 & 50,0 & 20 & 38,5 & 46 & 88,5 & & \\
\hline Total & 31 & 59,6 & 21 & 40,4 & 52 & 100 & & \\
\hline
\end{tabular}

\section{BAHASAN}

Penelitian ini dilakukan terhadap 52 laki-laki dewasa muda dengan obesitas sentral yang terdiri dari 31 orang yang terdiagnosis HVK (kelompok kasus) dan 21 orang yang tidak mengalami HVK (kelompok kontrol). Hasil penelitian ini menunjukkan bahwa subyek terbanyak (52\%) berada pada kelompok usia 21-25 tahun, disusul kelompok usia 16-20 tahun (34,5\%), dan terakhir 26-30 tahun (13,5\%). Semakin bertambahnya usia semakin besar peluang seseorang mengalami HVK. Hasil ini tidak sejalan dengan penelitian oleh Wantania dan Lefrandt ${ }^{8}$ yang melaporkan bahwa HVK pada laki-laki dewasa muda (20-40 tahun) dengan obesitas sentral paling banyak ditemukan pada usia 35-40 tahun.

Prevalensi perokok di Indonesia pada tahun 2013 sebanyak 29,3\%. Proporsi terbanyak perokok aktif setiap hari pada usia 30-34 tahun sebesar 33,4\% dan pada usia 35-39 tahun sebesar 32,2\%. Proporsi perokok setiap hari pada laki-laki lebih banyak dibandingkan pada perempuan (47,5\% banding $1,1 \%)$. Berdasarkan jenis pekerjaan, petani/nelayan/buruh merupakan proporsi perokok aktif setiap hari yang terbesar $(44,5 \%)$ dibandingkan kelompok pekerjaan lainnya. $^{3}$

Pada penelitian ini, subyek yang memiliki kebiasaan merokok paling banyak terdapat pada kelompok kasus yaitu sebanyak 5 orang $(9,6 \%)$, sedangkan pada kelompok kontrol terdapat 1 orang $(1,9 \%)$ dengan kebiasaan merokok. Subyek yang tidak merokok paling banyak ditemukan pada kelompok kasus sebanyak 26 orang (50\%) dibandingkan 20 orang $(38,5 \%)$ pada kelompok kontrol. Rendahnya jumlah perokok pada subyek penelitian yaitu mahasiswa laki-laki peserta KKM di FK Unsrat mungkin disebabkan latar belakang medisnya sebagai mahasiswa Fakultas Kedokteran. Selain itu, rumah sakit merupakan area terlarang untuk merokok.

Hasil pengolahan data untuk merokok menunjukkan bahwa terdapat 6 subyek $(11,5 \%)$ yang memiliki kebiasaan merokok, 5 di antaranya $(9,6 \%)$ terdapat pada kelompok kasus yang mengalami HVK. Hasil analisis bivariat dengan menggunakan uji chi-square membuktikan bahwa tidak terdapat hubungan antara kebiasaan merokok dengan kejadian HVK $(P=0,432)$. Hasil penelitian ini tidak selaras dengan penelitian yang dilakukan oleh Dwivedi dan Sharma ${ }^{9}$ yang mendapatkan lebih banyak perokok pada subjek hipertensi dengan HVK dibandingkan dengan yang tidak HVK $(P=0,003)$. Dari 41 subjek yang merokok ditemukan 25 orang $(61 \%)$ yang mengalami HVK dibandingkan hanya 5 orang $(21,7 \%)$ yang mengalami HVK pada kelompok subyek yang tidak merokok. 
Penelitian yang dilakukan oleh Marcus et al. ${ }^{10}$ juga mendapatkan peningkatan massa ventrikel kiri yang bermakna pada kelompok perokok dibandingkan dengan yang tidak merokok $(P=0,036) .{ }^{10}$ Hasil yang serupa dilaporkan oleh Payne et al. ${ }^{11}$ yaitu terdapat hubungan antara merokok dengan respons pertumbuhan massa ventrikel kiri $(P=0,026)$.

Kurangnya subyek yang perokok, baik pada kelompok kasus maupun kontrol (hanya 5 dan 1 orang), serta selisih di antara kedua kelompok yang sangat tipis (4 subyek) dapat menjadi penyebab tidak terdapat hubungan secara statistik antara merokok dengan HVK. Hal ini mungkin disebabkan latar belakang medis dari para subyek penelitian sehingga jumlah subyek yang merokok tidak banyak, apalagi subyek penelitian ini bertugas di rumah sakit yang merupakan daerah bebas asap rokok.

Hasil Riskesdas 2013 memperlihatkan prevalensi penduduk usia 15 tahun ke atas yang merokok setiap hari, secara nasional sebesar 24,3\% sedangkan di Sulawesi Utara sebesar 24,6\%. Hal ini menunjukkan bahwa penduduk di Sulawesi Utara merokok setiap hari lebih banyak dibandingkan dengan prevalensi secara nasional. World Health Organization menyatakan bahwa rokok membunuh lebih dari lima juta orang per tahun, dan diproyeksikan akan membunuh 10 juta sampai tahun 2010. Demikian pula Lembaga Demografi UI mencatat, angka kematian akibat penyakit yang disebabkan rokok pada tahun 2004 ialah 427.948 jiwa, berarti 1.172 jiwa per hari atau sekitar 22,5\% dari total kematian di Indonesia. $^{12}$

Merokok merupakan salah satu faktor yang berhubungan dengan hipertensi disebabkan kandungan nikotin dalam rokok. Menghisap rokok menyebabkan nikotin terserap oleh pembuluh darah kecil dalam paru-paru dan kemudian akan diedarkan hingga ke otak. Di dalam otak, nikotin akan memberikan sinyal pada kelenjar adrenal untuk melepas epinefrin atau adrenalin yang akan menyempitkan pembuluh darah dan memaksa jantung untuk bekerja lebih berat karena tekanan darah yang lebih tinggi. Merokok akan menurunkan fungsi vasodilatasi arteri melalui penurunan kemampuan dari nitrik oksida. In vitro, nikotin akan menstimulasi proliferasi selsel endotel dan sel-sel otot polos, termasuk kardiomiosit. Proliferasi kardiomiosit pada akhirnya akan menyebabkan hipertrofi ventrikel kiri. ${ }^{13}$

Selain melalui jalur hipertensi, merokok juga dapat menyebabkan terjadinya HVK lewat proses inflamasi. Kandungan nikotin dalam rokok ternyata berhubungan dengan HVK pada penelitian menggunakan hewan coba. Pada tikus, inhalasi kronik karbonmonoksida akan menginduksi terjadinya hipertrofi jantung. Pertumbuhan massa ventrikel kiri sebagai respons dari infark miokard juga lebih tampak pada kelompok tikus yang terpapar dengan karbonmonoksida. $^{13}$ Selain itu, nikotin mengganggu sistem saraf simpatis dengan akibat meningkatnya kebutuhan oksigen miokard, yang bila berlangsung dalam jangka waktu cukup lama dapat menyebabkan nekrosis pada sebagian kardiomiosit. Nikotin juga akan menyebabkan terbentuknya reactive oxygen species (ROS) di dalam tubuh, yang kemudian memicu pelepasan sitokin-sitokin proinflmasi seperti TNF- $\alpha$ dan IL-6. Perlekatan TNF- $\alpha$ dengan reseptornya di otot jantung akan mengakibatkan apoptosis kardiomiosit dan hipertofi kardiomiosit lainnya sebagai kompensasi. ${ }^{14,15}$

\section{SIMPULAN}

Berdasarkan hasil penelitian ini dapat disimpulkan bahwa kebiasaan merokok merupakan faktor risiko terjadinya hipertrofi ventrikel kiri pada laki-laki dengan obesitas sentral usia dewasa muda $(<30$ tahun) walaupun secara statistik tidak bermakna

\section{DAFTAR PUSTAKA}

1. Kannel WB. Left ventricular hypertrophy and mortality-Results for the Framingham Study. Cardiology. 1992;81:291-8.

2. Horrower A, Mc Farlane G. Left ventricular hypertrophy in hypertension. Am J 
Med. 1998;1B(S):89-91.

3. Depkes RI. Kementrian Kesehatan Republik Indonesia. Badan Penelitian dan Pengembangan Kesehatan. Riset Kesehatan Dasar, 2013.

4. Hotamisligil GS, Arner P, Caro JF, Atkinson RL. Increased adipose tissue expression of tumor necrosis factoralpha in human obesity and insulin resistance. J Clin Invest. 1995;95(5): 2409-15.

5. Zahorska B, Janowska J, Olszanecka M, Zurakowski A. Serum concentrations of TNF-alpha and soluble TNF-alpha receptors in obesity. Int $\mathrm{J}$ Obes Relat Metab Disord. 2000;24(11):1392-5.

6. Nasution SA. Kardiomiopati. In: Buku Ajar Ilmu Penyakit Dalam. Jakarta: Interna Publishing, 2009; p. 1720-7.

7. Oemar H. Textbook of Echocardiography (1st ed). Jakarta: YMB Publisher, 2005; p. 179-92.

8. Wantania FE, Lefrandt RL, Panda AL. Correlation of TNF-alpha with the left venticular hypertrophy and prehypertension in non diabetes male abdominal obesity. Jakarta: Annual Scientific Meeting of Indonesian Heart Association, 2013.

9. Dwivedi S, Sharma S. Interlink between smoking and left ventricular hypertrophy in hypertensive Nepali subjects.
JIACM. 2005;5(1):93-4.

10. Marcus MRP, Stritzke J, Baumeister SE, Siewert U, Baulmann J, Hannemann A, et al. Effects of smoking on arterial distensibility, central aortic pressures and left ventricular mass. Int J Cardiol. 2013;168(3):2593-601.

11. Payne JR, Eleftheriou KI, James LE, Haes E, Mann J, Stronge A, et al. Left ventricular growth response to exercise and cigarette smoking: data from LARGE Heart. Heart. 2006;92(12): 1784-8.

12. Bustan MN. Epidemiologi penyakit tidak menular (Cetakan 2). Jakarta: Rineka Cipta, 2007.

13. Loennechen JP, Nilsen OG, Arbol I, Aadahl P, Nilsen T, Waldum HL, et al. Chronic exposure to carbon monoxide and nicotine: endothelin ET(A) receptor antagonism attenuates carbon monoxide-induced myocardial hypertrophy in rat. Toxicol Appl Pharmacol. 2002;178(1):8-14.

14. Alpert MA. Obesity cardiomyopathy: pathophysiology and evolution of the clinical syndrome. Am J Med Sci. 2001; 321(4):225-36.

15. Baumgarten G, Knuefermann $P$, Mann DL. Cytokines as emerging targets in the treatment of heart failure. Trends Cardiovasc Med. 2000;10(5):216-23. 